\title{
EVALUATION OF ENDANGERED LAKESUCKER REARING IN TRIBUTARIES TO UPPER KLAMATH LAKE BY USE OF X-RAY IMAGING
}

\author{
Molly F. Hayes ${ }^{1,2}$ and Josh E. Rasmussen ${ }^{1}$
}

\begin{abstract}
Aвstract--Two species of endangered, primarily lake-dwelling sucker are endemic to the Upper Klamath Basin in southern Oregon: shortnose sucker (Chasmistes brevirostris) and Lost River sucker (Deltistes luxatus). A third unlisted species, Klamath largescale sucker (Catostomus snyderi), also occurs in the basin. Apart from a small group of adult Lost River suckers documented in a tributary to Upper Klamath Lake in the late 1990s, it is generally believed that though the listed sucker species spawn in tributaries, the larvae out-migrate within days of swim-up, and therefore, there is no juvenile residence in the tributaries. We used X-ray imaging and vertebral counts to identify 347 juvenile suckers collected from tributaries to Upper Klamath Lake between 2006 and 2008 . We positively identified 13 individuals as Lost River sucker. Our finding of juvenile endangered suckers rearing in tributaries to Upper Klamath Lake challenges the previous finding that larval and juvenile suckers only spend a small portion of their lives in rivers. This finding may have broader implications for future research and management of endangered suckers in the Klamath Basin.
\end{abstract}

RESUMEN.-Dos especies de matalote en peligro de extinción y principalmente de lago vivienda son endémicas de la superior de la cuenca de Klamath en el sur de Oregon: el matalote nariz-corta (Chasmistes brevirostris) y el matalote de Lost River (Deltistes luxatus). Una tercera especie de matalote no listado, matalote del gran escala de Klamath (Catostomus snyderi), también occurre en la cuenca. Aparte de un pequeño grupo de adultos del matalote de Lost River documentado en un afluente del lago de Upper Klamath en la década de 1990, se cree generalmente que, aunque las especies de matalotes listadas desovan en los afluentes, las larvas a cabo migrar los pocos días de salir de la grava, y por lo tanto los juveniles no se hacen maduros en los afluentes. Usamos imágenes de rayos X y los recuentos vertebrales para identificar hasta las especies 347 matalote juveniles recogidos de afluentes del lago Upper Klamath entre 2006 y 2008. Se identificaron positivamente a 13 individuos como matalote de Lost River. Nuestro hallazgo de juveniles de matalote en peligro de extinción criandose en las afluentes al lago de Upper Klamath se opone a la conclusión anterior de que matalote larvas y juveniles de gastar sólo una pequeña parte de su vida en los ríos. Este hallazgo puede tener implicaciones más amplias para la investigación y la gestión de matalote en peligro de extinción en la cuenca del Klamath.

Two species of sucker are endemic to the Klamath Basin: the shortnose sucker (Chasmistes brevirostris) and Lost River sucker (Deltistes luxatus). These species are longlived, large-bodied iteroparous fishes that belong to the family Catostomidae, particularly as members of a group that primarily reside in lakes and reservoirs (Scoppettone and Vinyard 1991, Moyle 2002, NRC 2004). The Shortnose sucker and Lost River sucker were historically abundant in the Klamath Basin before the populations began to decline around the 1960s (Markle and Cooperman 2002, Cooke et al. 2005). In 1974 shortnose sucker and Lost River sucker were listed as endangered by the state of California, and in 1988 both species were listed as endangered under the federal Endangered Species Act and by the state of Oregon (USFWS 1988, CDFG 2010). Since the listing of these species, population numbers have continued to decline, and a lack of recruitment has resulted in populations mainly composed of older individuals (Scoppettone and Vinyard 1991, Janney and Shively 2007, Janney et al. 2008). The unnaturally high larval and juvenile mortality driving these demographic patterns is likely due to poor water quality and habitat loss (Simon and Markle 2002, NRC 2004, Hendrixson et al. 2007, Janney et al. 2008, Burdick and Brown 2010, Hewitt et al. 2011, Burdick and Hewitt 2012). A third sucker species, Klamath largescale sucker (Catostomus snyderi), is also endemic to the Upper Klamath Basin, but this species is not listed as endangered and predominantly inhabits the lotic habitats of the basin.

Shortnose suckers and Lost River suckers in Upper Klamath Lake spend the majority of their lives in the lake, migrating as adults into

\footnotetext{
${ }^{1}$ United States Fish and Wildlife Service, Klamath Falls, OR

${ }^{2}$ E-mail: molly_hayes@fws.gov
} 
tributaries to spawn. Shortnose suckers exclusively spawn in tributaries while about $10 \%$ of Lost River suckers also spawn at springs along the lakeshore (Buettner and Scoppettone 1990, NRC 2004, Tyler et al. 2004, Ellsworth et al. 2007). Between April and July, eggs in tributaries hatch and, shortly after swim-up, larval suckers passively drift downstream to the lake (Klamath Tribes 1996, Tyler et al. 2004, Ellsworth et al. 2010). While a small number of adult Lost River suckers have been documented in the Sprague River near Beatty, Oregon (L. Dunsmoor, Klamath Tribes, unpublished data), it is generally believed that larvae leave the river systems within $4-5$ days after swim-up (Cooperman and Markle 2003) and return only to spawn after at least 3 years of rearing (Rasmussen 2011, USFWS 2013).

Adult shortnose sucker, Lost River sucker, and Klamath largescale sucker can be identified to species on the basis of head and mouth morphology; however, this method is inadequate for juvenile identification given the lack of external morphological and meristic differences among the species. Juvenile Lost River sucker can be distinguished from shortnose sucker and Klamath largescale sucker by the number of vertebrae posterior to the Weberian apparatus, a structure that develops from the first few vertebrae and connects the swim bladder to the auditory system in fishes in the Ostariophysi superorder (Markle et al. 2005). Lost River sucker generally has a postWeberian vertebral count of $\geq 45$ while shortnose sucker and Klamath largescale sucker have $\leq 43$ post-Weberian vertebrae (Markle et al. 2005). A vertebral count of 44 is inconclusive and could be any of the 3 species. Also, approximately $2.5 \%$ of Klamath largescale suckers have vertebral counts greater than 44 (Markle et al. 2005).

Between 2006 and 2008, juvenile suckers $(n=347)$ were collected from 14 sites on tributaries within the Williamson River drainage to Upper Klamath Lake (Fig. 1) as part of an effort to assess the relative abundance, species composition, and emigration timing of juvenile fishes. Three of these sites were sampled using 8-foot-diameter rotary screw traps, while the remaining sites were electrofished using a portable backpack shocker. A subset of the captured suckers were anesthetized with MS-222 (Western Chemical, Inc., Ferndale, WA), in accordance with humane handling techniques and relevant federal and state permits, and subsequently preserved in $95 \%$ ethanol for later identification. In 2015 the preserved suckers were numbered, marked with numeric tags, and sorted according to body size. In 2016 the suckers were x-rayed. Fish of similar sizes were laid on X-ray slides to ensure that all specimens were in focus, and each slide was marked with a distinguishing number and letter combination, photographed, and x-rayed. Digital X-ray images were converted to JPG format and post-Weberian vertebrae were counted for each specimen (Fig. 2). Two readers independently counted vertebrae for each specimen using landmark placement within tpsDig2 software (F.J. Rohlf, Ecology and Evolution, SUNY at Stony Brook, Stony Brook, NY) and counts were compared. If counts differed, vertebrae were recounted jointly to determine if a consensus could be achieved. All final counts were based on consensus.

Specimens were identified to species based on vertebral count using the abovementioned criteria. There is a chance that the individuals with vertebral counts $>44$ are in fact Klamath largescale sucker, which are typically considered to be more of a riverine species. Of the 84 adult suckers examined by Markle et al. (2005) with $>44$ post-Weberian vertebrae, 81 (96.4\%) were Lost River sucker. Furthermore, no consistently reliable means were available to obtain better resolution on these juveniles. Gill raker counts could not be used for species identification because counts would likely be unreliable due to the condition of the specimens and the passage of time. All specimens will be maintained at the U.S. Fish and Wildlife Service office in Klamath Falls, Oregon.

Of the 347 fish analyzed, 277 individuals had $\leq 43$ post-Weberian vertebrae and were identified as either shortnose sucker or Klamath largescale sucker, 57 individuals had 44 postWeberian vertebrae leading to an inconclusive identification, and 13 individuals had $\geq 45$ vertebrae and were identified as Lost River sucker (Table 1). Individuals identified as Lost River sucker ranged in standard length (SL) from 37 to $96 \mathrm{~mm}(\bar{x}=61.5$, SD 18.5). Those identified as either of the other species ranged in standard length (SL) from 44 to $96 \mathrm{~mm}(\bar{x}=$ 60.4, SD 15.6). Fish were not aged using hard structures, but it appeared that most fell 


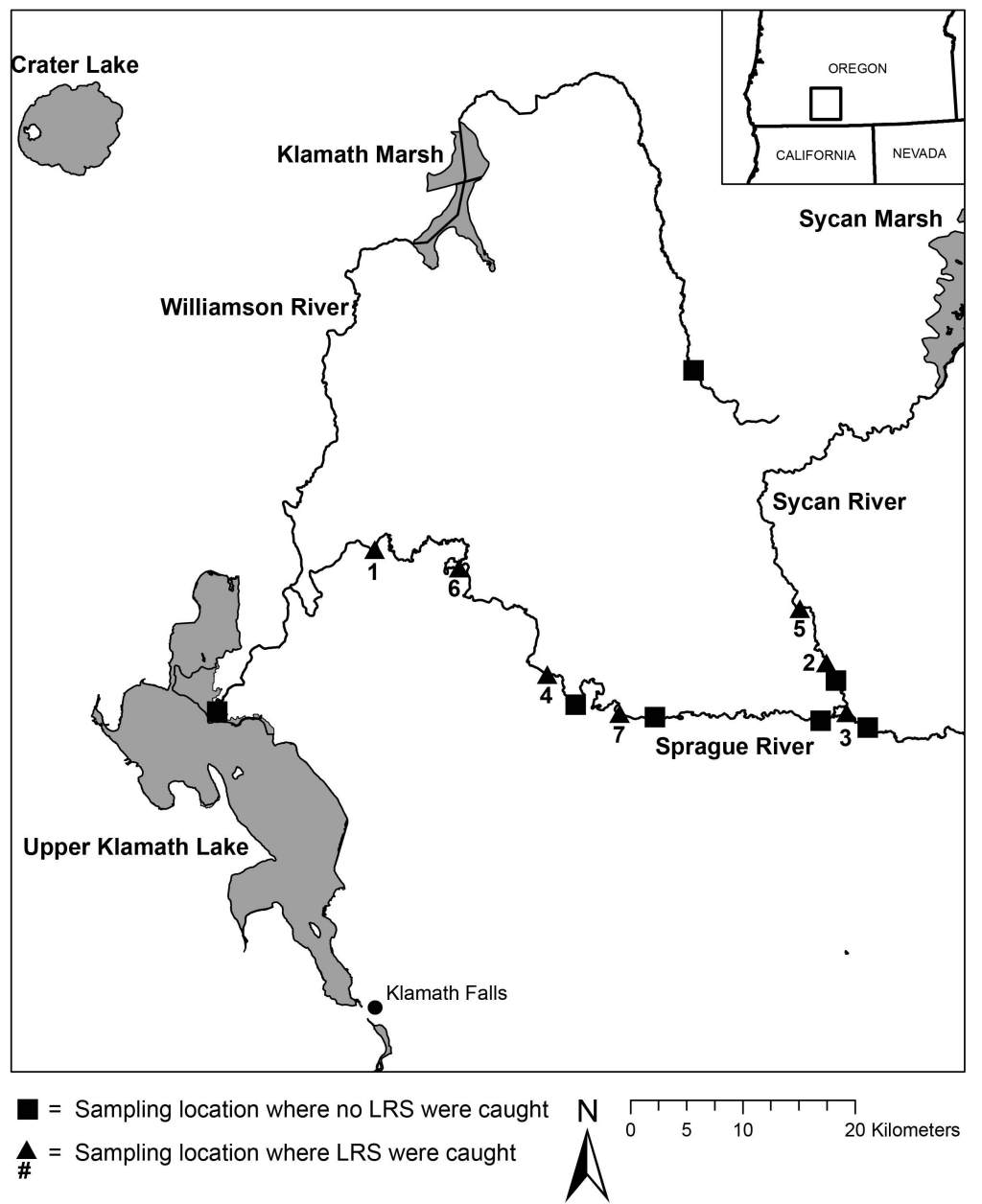

Fig. 1. Map of the Upper Klamath Basin of south central Oregon showing locations of all sites sampled and sites where juvenile Lost River suckers (LRS) were captured, indicated by the symbols. The numbers for capture sites correspond with the numbering in Table 1.

within the size range of young-of-the-year, with the exception of the individual captured at site 1 on 31 May 2006 with a standard length (SL) of $82 \mathrm{~mm}$. This individual was at least one year old given its length and the time of year.

Sampling sites 2, 3, and 5 are near the location where adult Lost River suckers were captured in the late 1990s in the Sprague River just to the east (upstream) of the confluence of the Sycan and Sprague Rivers. Sites 1 and 6 are also relatively close (upstream) to the primary Lost River sucker spawning area, but sites 4 and 7 are not close to any known spawning areas.

The discovery of juvenile Lost River suckers in tributaries to Upper Klamath Lake challenges the current paradigm that suckers only spend a few days of their lives in rivers as larvae and juveniles. However, our findings do not indicate whether the juveniles in the tributaries represent a significant portion of the population or divergent life histories. Other researchers have noted that although Lost River suckers outnumber shortnose suckers and Klamath largescale suckers in the lower spawning areas-perhaps by an order of magnitude (Hewitt et al. 2011) — this numeric dominance is not found in larval captures, which are often nearly equivalent (Ellsworth et al. 2010, 2011). If even a portion of Lost River suckers remain in the riverine habitats, we may observe these patterns. Our focus on Lost 

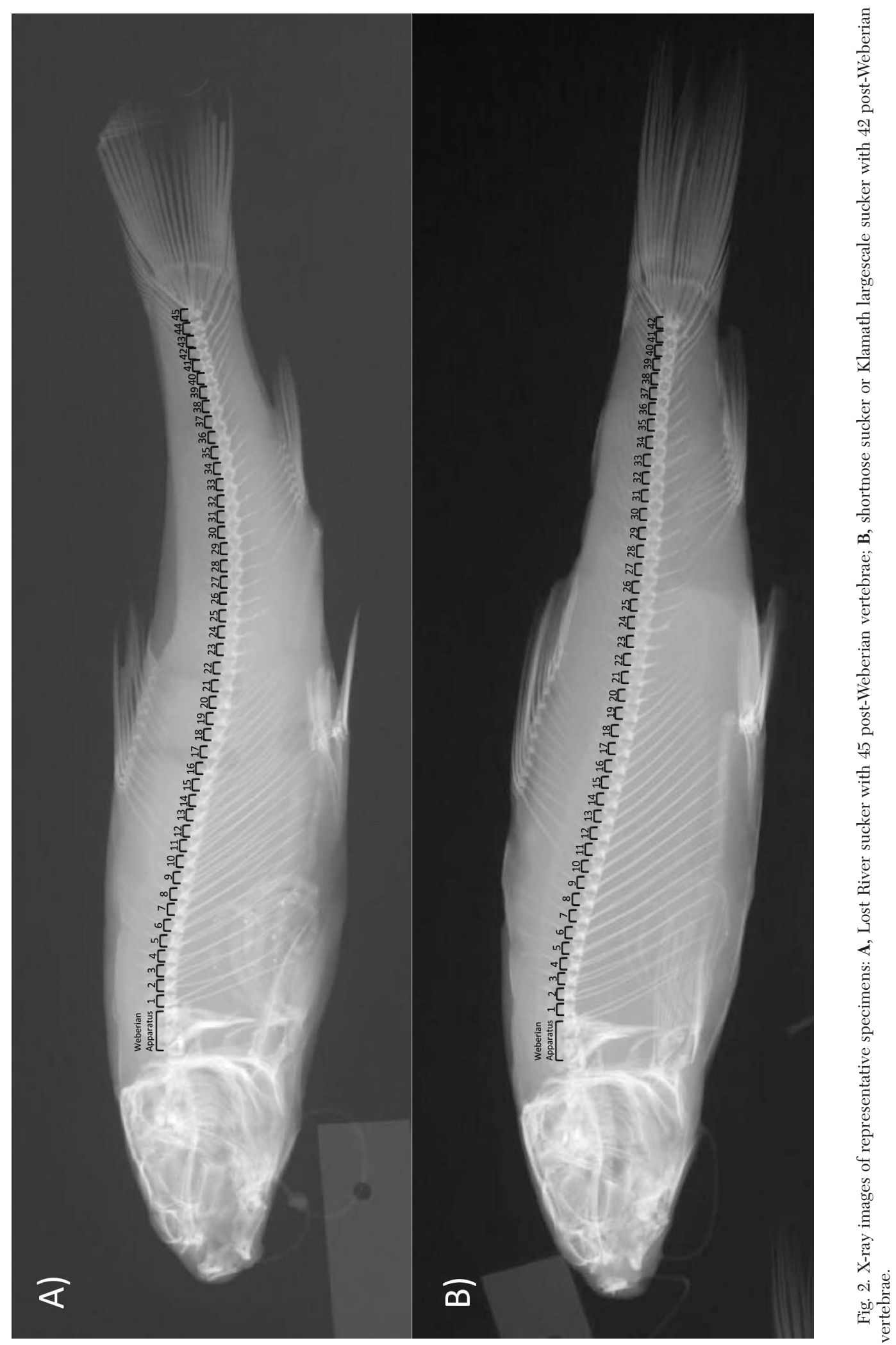
TABLE 1. Thirteen Lost River suckers captured in the Williamson River drainage between 2006 and 2008 using screw traps and electrofishing. The site number corresponds with sites indicated in Fig. 1.

\begin{tabular}{lclc}
\hline $\begin{array}{l}\text { Date } \\
\text { collected }\end{array}$ & $\begin{array}{c}\text { Site } \\
\text { number }\end{array}$ & $\begin{array}{l}\text { Capture } \\
\text { method }\end{array}$ & $\begin{array}{c}\text { Standard } \\
\text { length }(\mathrm{mm})\end{array}$ \\
\hline 31 May 2006 & 1 & Screw trap & 82 \\
28 Jul 2006 & 2 & Electrofishing & 45 \\
10 Aug 2006 & 3 & Electrofishing & 52 \\
1 Sep 2006 & 1 & Screw trap & 76 \\
8 Sep 2006 & 1 & Screw trap & 78 \\
22 Sep 2006 & 1 & Screw trap & 85 \\
18 Sep 2007 & 4 & Electrofishing & 57 \\
21 Sep 2007 & 1 & Screw trap & 96 \\
24 Sep 2007 & 5 & Electrofishing & 61 \\
23 Jun 2008 & 6 & Electrofishing & 37 \\
1 Jul 2008 & 7 & Screw trap & 44 \\
1 Jul 2008 & 7 & Screw trap & 46 \\
28 Oct 2008 & 8 & Electrofishing & 61 \\
\hline
\end{tabular}

River sucker should not be construed to mean that shortnose sucker juveniles do not also occur in lotic habitats more than previously believed; our data are simply not able to inform that question due to our inability to accurately distinguish between shortnose sucker and Klamath largescale sucker.

An estimate of the total number of Lost River suckers rearing in tributaries to Upper Klamath Lake cannot be extrapolated from these data; therefore, the overall significance is difficult to assess; nevertheless, the presence of any number is noteworthy. Low recruitment and reduced age-class diversity in Upper Klamath Lake have led to extensive research on sucker survival, ecosystem restoration, and efforts to create auxiliary populations (USFWS 2013). Nonetheless, the last substantial recruitment to adult spawning populations was in the late 1990s (USFWS 2013). Finding juvenile endangered suckers rearing in tributaries to Upper Klamath Lake could promote understanding of population dynamics within the lake if differentials exist in survival, recruitment, or other metrics such as condition or parasite loads. Tributaries could also serve as refugial habitat, which will likely become increasingly important as climate changedriven temperature increases lead to deteriorating conditions in Upper Klamath Lake. While the current recovery plan for shortnose sucker and Lost River sucker primarily prioritizes improving juvenile recruitment in Upper Klamath Lake, it also identifies a need to assess the use of rearing habitat by endangered suckers in the Sprague River as an objective to accomplish that goal (USFWS 2013). This evidence that there may be a group of putative Lost River suckers (and potentially shortnose suckers) that rear in rivers rather than rearing in the lake begins to address this recovery action. These findings should be included in the conversation about management and conservation considerations; however, they do not necessarily mean that research and recovery of endangered suckers rearing in lotic habitats should become a priority. Additional research is needed to assess shortnose sucker and Lost River sucker distribution, demographics, and health in tributaries to Upper Klamath Lake.

We gratefully acknowledge the assistance and hard work of M. Buettner, C. Chew, T. Esson, K. Farrar, S. Garcia, J. Hodge, K. Moyer, J. Murphy, A. Richardson, E. Spiess, A. Sutton, C. Yanos, and S. Allen. We gratefully thank the Oregon Institute of Technology Radiologic Science Department and Radiologic Science Club for their assistance with this effort. The findings and conclusions in this article are those of the authors and do not necessarily represent the views of the U.S. Fish and Wildlife Service.

\section{Literature Cited}

Buettner, M., And G. SCOPpetTone. 1990. Life history and status of catostomids in Upper Klamath Lake, Oregon: completion report. Reno Field Station, National Fisheries Research Center, U.S. Fish and Wildlife Service, U.S. Department of Interior, Reno, NV.

Burdick, S.M., AND D.T. Brown. 2010. Distribution and condition of larval and juvenile Lost River and shortnose suckers in the Williamson River Delta restoration project and Upper Klamath Lake, Oregon—2009 annual data summary. U.S. Geological Survey OpenFile Report 2010-1216. 78 pp.

Burdick, S.M, AND D.A. HewitT. 2012. Distribution and condition of young-of-year Lost River and shortnose suckers in the Williamson River Delta restoration project and Upper Klamath Lake, Oregon, 2008-10, Final Report. U.S. Geological Survey Open-File Report 2012-1098. 52 pp.

[CDFG] California Department of Fish and Game. 2010. State and federally listed endangered and threatened animals of California. Natural Resources Agency, State of California, Sacramento, CA.

Cooke, S.J., C.M. Bunt, S.J. Hamilton, C.A. Jennings, M.P. Pearson, M.S. Cooperman, and D.F. Markle. 2005. Threats, conservation strategies, and prognosis for suckers (Catostomidae) in North America: insights from regional case studies of a diverse family of nongame fishes. Biological Conservation 121:317-331.

Cooperman, M.S., and D.F. Markle. 2003. Rapid outmigration of Lost River and shortnose suckers from in-river spawning beds to in-lake rearing grounds. 
Transactions of the American Fisheries Society 132:1138-1153.

Ellsworth, C.M., D.T. Banks, and S.P. VanderKooi. 2011. Patterns of larval sucker emigration from the Sprague and lower Williamson Rivers of the Upper Klamath Basin, Oregon, prior to the removal of Chiloquin Dam-2007/2008 annual report. U.S. Geological Survey Open File Report 2011-11-8. 30 pp.

Ellsworth, C.M., T.J. Tyler, C.D. Luton, S.P. VANDERKOOI, AND R.S. SHIVELY. 2007. Spawning migration movements of Klamath largescale, Lost River, and shortnose suckers in the Williamson River and Sprague Rivers, Oregon, prior to the removal of Chiloquin Dam. Klamath Falls Field Station, Western Fisheries Research Station, U.S. Geological Survey, U.S. Department of Interior, Klamath Falls, OR.

Ellsworth, C.M., T.J. Tyler, and S.P. Vanderkooi. 2010. Using spatial, seasonal, and diel drift patterns of larval Lost River suckers Deltistes luxatus (Cypriniformes: Catostomidae) and shortnose suckers Chasmistes brevirostris (Cypriniformes: Catostomidae) to help identify a site for a water withdrawl structure on the Williamson River, Oregon. Environmental Biology of Fishes 89:47-57.

Hendrixson, H.A., S.M. BURdick, and S.P. Vanderkooi. 2007. Near-shore and offshore habitat use by endangered, juvenile Lost River and shortnose suckers in Upper Klamath Lake, Oregon-Annual report 2004. Report of U.S. Geological Survey, Western Fisheries Research Center, Klamath Falls Field Station to Bureau of Reclamation, Mid-Pacific Region, Klamath Falls, OR. 94 pp.

Hewitt, D.A., B.S. Hayes, E.C. Janney, A.C. Harris, J.P. Koller, AND M.A. Johnson. 2011. Demographics and run timing of adult Lost River (Deltistes luxatus) and shortnose (Chasmistes brevirostris) suckers in Upper Klamath Lake, Oregon, 2009. U.S. Geological Survey Open-File Report 2011-1088. 38 pp.

JanNey, E.C., AND R.S. SHIVELY. 2007. An updated analysis on the population dynamics of Lost River suckers and shortnose sucker in Upper Klamath Lake and its tributaries, Oregon. Klamath Falls Field Station, Western Fisheries Research Station, U.S. Geological Survey, U.S. Department of Interior, Klamath Falls, OR.

Janney, E.C., R.S. Shively, B.S. Hayes, P.M. Barry, and D. Perkins. 2008. Demographic analysis of Lost River sucker and shortnose sucker populations in Upper Klamath Lake, Oregon. Transactions of the American Fisheries Society 137:1812-1825.

Klamath Tribes. 1996. A synopsis of the early life history and ecology of Catostomids, with a focus on the Williamson River Delta. Unpublished report prepared by The Klamath Tribes Natural Resources Department in conjunction with the Fish Subcommittee of the Lower Williamson River Restoration Team, Chiloquin, OR.

Markle, D.F., M.R. Cavalluzzi, and D.C. Simon. 2005. Morphology and taxonomy of Klamath Basin suckers
(Catostomidae). Western North American Naturalist 65:473-489.

Markle, D.F., and M.S. Cooperman. 2002. Relationship between Lost River and shortnose sucker biology and management of Upper Klamath Lake. Pages 93-117 in B. Braunworth and T. Welch, editors, Water allocation in the Klamath Reclamation Project, 2001: an assessment of natural resource, economic, social, and institutional issues with a focus on the Upper Klamath Basin. Oregon State University [and University of California], Corvallis, OR.

Moyle, P.B. 2002. Inland fishes of California. University of California Press, Berkeley, CA

[NRC] National Research Council. 2004. Endangered and threatened fishes in the Klamath River Basin: cause of decline and strategies for recovery. National Academies Press, Washington, DC.

Rasmussen, J.E. 2011. Status of Lost River sucker and shortnose sucker. Western North American Naturalist 71:442-455.

ScoppetTone, G.G., And G. Vinyard. 1991. Life history and management of four lacustrine suckers. Pages 359-377 in W.L. Minckley and J.E. Deacon, editors, Battle against extinction: native fish management in the American West. University of Arizona Press, Tucson, AZ

Simon, D.C., AND D.F. MarkLe. 2002. Ecology of Upper Klamath Lake shortnose and Lost River suckersannual survey of abundance and distribution of age-0 shortnose and Lost River suckers in Upper Klamath Lake-2001 annual report. Report of Oregon Cooperative Research Unit, Department of Fisheries and Wildlife, Oregon State University to U.S. Biological Resources Division, U.S. Geological Survey, Corvallis, OR, and Klamath Project, Bureau of Reclamation, Klamath Falls, OR. 63 pp.

Tyler, T.J., E.C. Janney, H.A. Hendrixson, and R.S. ShivELY. 2004. Monitoring of Lost River and shortnose suckers in the lower Williamson River. Unpublished report submitted to the Bureau of Reclamation, U.S. Department of the Interior, Klamath Falls, OR.

[USFWS] United States Fish and Wildlife SERvice. 1988. Final rule: endangered and threatened wildlife and plants: determination of endangered status for the shortnose sucker and Lost River sucker. Federal Register 53:27130-27134.

[USFWS] United States Fish and Wildlife Service. 2013. Revised recovery plan for the Lost River sucker (Deltistes luxatus) and shortnose sucker (Chasmistes brevirostris). U.S. Fish and Wildlife Service, Pacific Southwest Region, Sacramento, CA. xviii +122 pp.

Received 4 October 2016

Accepted 9 November 2016

Published online 29 March 2017 